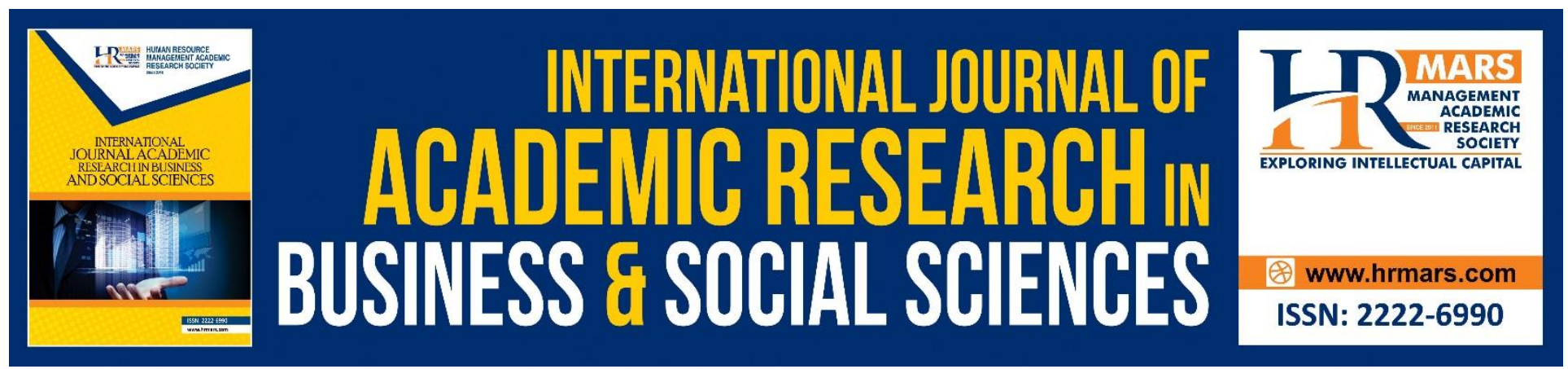

\title{
Capital Structure, Liquidity, Sales Growth on Firm Value: Evidence in Indonesia Stock Exchange
}

\section{Agoestina Mappadang}

To Link this Article: http://dx.doi.org/10.6007/IJARBSS/v10-i8/7524

DOI:10.6007/IJARBSS/v10-i8/7524

Received: 19 May 2020, Revised: 20 June 2020, Accepted: 15 July 2020

Published Online: 24 August 2020

In-Text Citation: (Mappadang, 2020)

To Cite this Article: Mappadang, A. (2020). Capital Structure, Liquidity, Sales Growth On Firm Value: Evidence In Indonesia Stock Exchange. International Journal of Academic Research in Business and Social Sciences, 10(8), 188-201.

\section{Copyright: (C) 2020 The Author(s)}

Published by Human Resource Management Academic Research Society (www.hrmars.com)

This article is published under the Creative Commons Attribution (CC BY 4.0) license. Anyone may reproduce, distribute, translate and create derivative works of this article (for both commercial and non-commercial purposes), subject to full attribution to the original publication and authors. The full terms of this license may be seen

at: http://creativecommons.org/licences/by/4.0/legalcode

\section{Vol. 10, No. 8, 2020, Pg. 188 - 201}




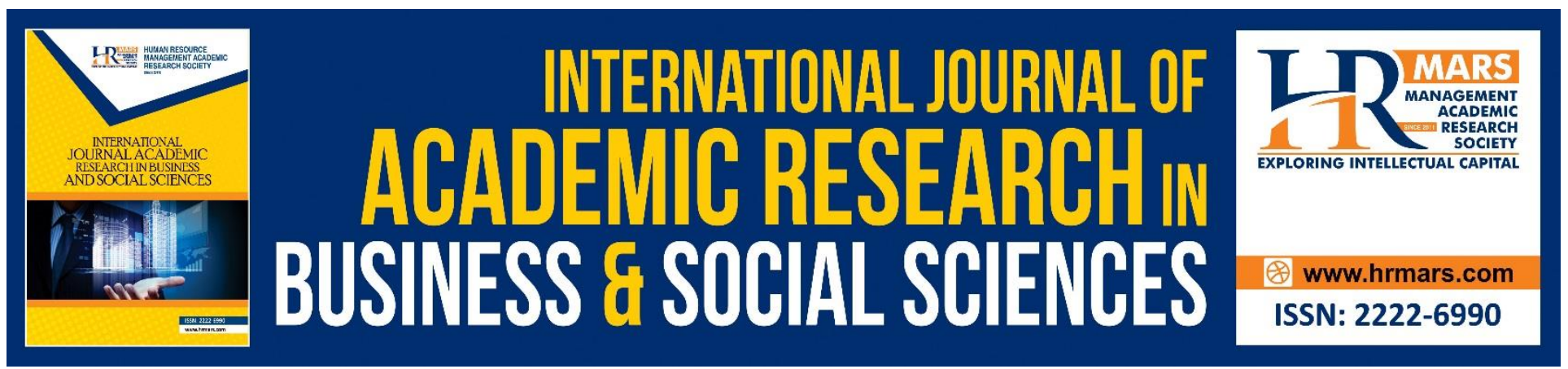

\title{
Capital Structure, Liquidity, Sales Growth on Firm Value: Evidence in Indonesia Stock Exchange
}

\author{
Agoestina Mappadang \\ Agoestina Mappadang, Department of Accounting, Economy, Universitas Budi Luhur \\ Jl. Ciledug raya, RT 10/RW 2, Petukangan Utara, Kec. Pesangrahan \\ Kota Jakarta Selatan, DKI Jakarta 12260, Indonesia \\ Email: gustinam7808@gmail.com
}

\section{Abstract}

This study aims to determine the significance of the effect of capital structure, liquidity and sales growth on company value. The population of this research is the food and beverage sub-sector manufacturing companies listed on the Indonesia Stock Exchange for the period of 2016-2018, with a population of 13 companies. Determination of the number of samples in this study using a purposive sampling method, the purpose of using purposive sampling is to obtain a representative sample in accordance with the criteria determined by the researchers. Data analysis techniques used in this study are multiple linear regression analysis techniques and hypothesis testing F-statistics to test influence simultaneously. This study also uses t-statistics to partially test the regression coefficients. The classical assumption test results show that there are no deviations from the classical assumptions. This shows that the available data meets the requirements to be analyzed with multiple linear regression models. From this study it was concluded that the Capital Structure variable simultaneously and partially had a positive effect on Firm Value, the Liquidity variable simultaneously and partially had a positive effect on Firm Value while the Sales Growth variable simultaneously and partially had no effect on the Firm Value variable.

Keyword: Capital Structure, Liquidity, Sales Growth, Firm Value.

\section{Introduction}

Globalization has an impact in the economic field on business and business competition. The development of increasingly rapid globalization has become unavoidable whether liked or not. This also makes business competition tougher. In general, a company that is established has short-term and long-term goals. The short term goal of a company is to maximize a profit or wealth. While the long-term goal of a company is to prosper shareholders by increasing the value of the company.

For an investor, creditors and stakeholders the value of the company is an important concept in determining investment in order to get capital gains and anticipate the risks that occur. Before making a decision to invest in the capital market they need an accurate analysis. In investing, investors, creditors and stakeholders will consider the best company to which their capital will be 
INTERNATIONAL JOURNAL OF ACADEMIC RESEARCH IN BUSINESS AND SOCIAL SCIENCES Vol. 10, No. 8, 2020, E-ISSN: 2222-6990 @ 2020 HRMARS

invested. To consider this, investors can see the value in the company. The higher the stock price, the higher the value of the company. One phenomenon that occurs related to the value of the company is the Salim Group company engaged in the consumer goods sector business that is believed to have good prospects. In 2019 the Salim Group's holding company, PT Indofood Sukses Makmur Tbk (INDF) posted a net value of Rp45.7 billion. So, with this net increase in value, INDF shares also rose to $2.78 \%$ to Rp7,400 per share. INDF shares that move from the lowest level of Rp7,275 per share to the highest level of Rp7,450 per share. INDF traded its shares and recorded a volume of 10.21 million shares with a frequency of 2,707 transactions. As for the transaction value collected, it reaches up to Rp75.22 billion. With the increase in the company's stock price which shows an increase in the company's value, this can also be responded to by the market. There are several factors that affect a company's value, including: capital structure, liquidity, and sales growth. Capital structure is a funding decision taken by a company to choose the right composition in choosing the optimal capital. A good capital structure will have an impact on the company and indirectly the company's financial position will increase and the value of the company will be high. However, in managing capital structure if there is an error it will also result in a large debt value, this will also lead to financial risks in the inability of the company to pay debts and interest expenses so that in this case the value of the company will also decline. To assess a company's value can also be seen from the company's performance which can be measured by financial ratios. One of the financial ratios is liquidity measured by Current Ratio. Liquidity is the ability of a company to meet short-term obligations on time. That is, if the value of a company's liquidity is high, it will reflect the company's high ability to meet or pay short-term obligations. A good company liquidity value will be considered as having a good performance by investors.

Company value can also be influenced by sales growth. Sales growth is the company's achievements in the past, because sales growth is used by companies to predict the company's achievements in the future. If sales growth is increasing every year, it will show a better company value. Except, provided the increase in sales is not followed by an increase in costs that exceed the level of sales growth. This can be used by investors as an indicator of their consideration to invest later in the company.

The research according to Sumarauw et al., (2015) found that the Capital Structure has positive and significant results on the value of the company. While other studies conducted by Dhani \& Utama (2017) have conflicting results, that the capital structure has a negative and significant value to the value of the company. Astuti \& Yadnya (2019) revealed that liquidity has a positive and significant effect on firm value. Another study was also conducted by Sudiani \& Darmayanti (2016) who have conflicting results that liquidity has a negative but not significant effect on firm value. Research by Trang et al., (2015) revealed the results of his research that sales growth had no significant positive effect on firm value. On the other hand, research conducted by Mandalika (2016) stimulant sales growth does not have a significant relationship to firm value nor partially has a significant relationship. Based on the background description and the existence of a research gap from previous studies regarding the relationship between Capital Structure, Liquidity, and Sales Growth on Firm Value, this study was conducted to re-examine the effect of Capital Structure, Liquidity, and Sales Growth on Firm Value in the manufacturing sector food and beverage listed on the Indonesia Stock Exchange for the period of 2016-2018. 
INTERNATIONAL JOURNAL OF ACADEMIC RESEARCH IN BUSINESS AND SOCIAL SCIENCES Vol. 10, No. 8, 2020, E-ISSN: 2222-6990 @ 2020 HRMARS

\section{Literature Review}

Signaling Theory by Brigham dan Houston (2001) revealed that a signal or signal is an action taken by a company to provide instructions to investors about how management views the company's prospects. If the manager has confidence that the company's prospects are good, and of course wants the stock price to increase, then the manager must communicate this to investors. Signal theory also explains why companies have the urge to provide financial statement information to external parties. There is a push for companies to provide information because there is information asymmetry between companies and future prospects rather than outside parties (investors and creditors). Lack of information from outside parties about the company can cause them to protect themselves by giving a low price to the company.

Companies can increase company value by reducing asymmetry. One way to reduce asymmetry is by giving signals to outsiders. The relationship of signal theory with this research shows that company value is often considered as a signal for investors in assessing the merits of a company, this is because the company's value can have an influence on the company's stock price. The increase in stock prices is considered as a signal that the company has good prospects in the future. The value of the company Company value is a description of the condition of a company. . (Sujoko dan Soebiantoro, 2007) stated that the value of the company is the investor's perception of the company's success rate which is closely related to its stock price. High stock prices will also create high company value. The increase, the value of the company is an achievement, which is in accordance with the wishes of the owners, because with the increasing value of the company, the welfare of the owners will also increase. Company value is also defined as market value. Various policies taken by management in an effort to increase the value of the company through increasing the prosperity of the owners and shareholders who are reflected in the share price (Brigham, 2006).

\section{Capital Structure}

Capital structure is a comparison between long-term sources that are loans and own capital sendiri (Husnan, 2001). (Sundjaja dan Barlian, 2003) state that capital structure is one of complex financial decisions because it is related to other financial decision variables. To achieve the company's goals in maximizing shareholder wealth, financial managers must be able to assess capital structure and understand its relationship to risk, yield or return on value. Capital structure has a target that is to create a composition of debt and venture capital that is most appropriate and most profitable in terms of debt and venture capital that is most appropriate and most profitable in terms of finance keuangan (Brigham and Houston, 2011).

Liquidity is a ratio used to measure a company's ability to meet its short-term obligations (Kasmir, 2010). Liquidity is used to measure a company's ability to pay short-term liabilities using its current assets. Companies that have sufficient ability to pay short-term obligations are referred to as liquid companies. Liquidity also relates to its ability to convert certain current assets into cash and demonstrate the strength of a company's funds to mark various operating activities of the company, make investments and pay for company obligations.

Liquidity is proxied by a current ratio. The higher the current ratio, the higher the ability of a company to pay short-term obligations. Conversely, the lower the current ratio, the lower the company's ability 
INTERNATIONAL JOURNAL OF ACADEMIC RESEARCH IN BUSINESS AND SOCIAL SCIENCES Vol. 10, No. 8, 2020, E-ISSN: 2222-6990 @ 2020 HRMARS

to pay short-term liabilities. Companies with high liquidity show the high ability of companies to meet their short-term obligations, namely companies in a healthy financial condition, and the higher the liquidity will increase the value of the company.

\section{Sales Growth}

Sales growth reflects the marketing performance of a company and is the company's competitiveness in the market. Sari (2013) states that increasing sales growth will encourage increased company value and make investors more confident and confident to invest their funds in the company. Sales also have a strategic influence on a company, because sales must be supported by assets or assets and if sales are increased, assets must be added (Weston dan Brigham, 2001). Sales from the previous year, the company can optimize its resources.

Sales growth has an important role in working capital management. By knowing how much sales growth, companies can predict how much profit they get. Companies with low levels of sales will affect profits, thereby impacting on the decline in corporate revenue. That is because increased sales can cover costs used during the production process, so company profits can also increase.

\section{Hypothesis Development}

\section{Relationship between Capital Structure and Firm Value}

Understanding capital structure according to Riyanto (2013) is a balance or comparison of a longterm debt with own capital. In the capital structure DER (Debt to Equity Ratio) is a ratio measuring the ability of companies to return the cost of debt through the company's own capital as measured by total debt and total capital (equity). Signaling Theory (Signal Theory) explains that companies with prospects profitable will try to avoid selling shares and trying every new capital needed by other means, including the use of debt that exceeds the target of normal capital structure. In the research of Sumarauw et al., (2015) found that the Capital Structure variable simultaneously had a positive and significant effect on Company Value. The sample used in the study was plastic and packaging companies listed on the Indonesia Stock Exchange in the period 2010-2013 with a total of 8 companies using purposive sampling methods.

Based on the description and results of previous studies, the hypotheses built are: H1: Capital Structure has a positive effect on Company Value

\section{Relationship between Liquidity and Company Value}

Liquidity is a company's ability to meet its short-term obligations. Liquidity management must be able to contribute to the realization of corporate value creation (Michalski, 2010). Because, good liquidity will be considered by investors to have good performance. In this case, investors will be interested to invest their capital in the company. (Sartono, 2000). (Astuti \& Yadnya, 2019) in their research which aims to examine the effect of dividend policy, liquidity, profitability and firm size on company value. The sample used in this study is manufacturing companies listed on the Indonesia Stock Exchange in the period 2010-2013 with a total of 20 companies using purposive sampling and using multiple linear regression analysis techniques. The results showed that the Dividend Policy, Liquidity, Profitability and Company Size partially had a positive and significant effect on Company Value. Based on the description and results of previous studies, the hypotheses built are:

H2: Liquidity has a positive effect on Company Value 
INTERNATIONAL JOURNAL OF ACADEMIC RESEARCH IN BUSINESS AND SOCIAL SCIENCES Vol. 10, No. 8, 2020, E-ISSN: 2222-6990 @ 2020 HRMARS

\section{Relationship between Sales Growth and Company Value}

Sales growth is an increase in the number of sales from year to year. Sales growth can reflect the company's ability to increase sales from time to time. Sales growth also reflects the manifestation of investment success in the past period that can be used as a prediction of future sales growth. Besides sales growth is also an indicator of demand and competitiveness of companies in an industry (Detiana, 2011). Trang et al., (2015) in his study aimed to examine the effect of Sales Growth, Company Size, ROA, and Capital Structure on Company Value. The sample used is that of companies listed on the LQ 45 Index 2009-2013. The research technique used is Purposive Sampling and obtained by 20 companies as research samples and using the Multiple Linear Regression test. The results showed that Sales Growth had no significant positive effect on Company Value, Company Size had a non-significant negative effect on Company Value. Whereas ROA and Capital Structure have a positive effect on Company Value.

Based on the description and results of previous studies, the hypotheses built are: H3: Sales Growth has a positive effect on Company Value

\section{Research Methodology \\ Population and Sample}

The population used in this study is the industrial manufacturing companies in the food and beverage sector. The sample is a part of the number and characteristics possessed by a population. In this study the number of samples taken were as many as 14 companies. This study uses a purposive sampling technique, where the samples are determined according to criteria determined by the researcher. The criteria determined in this study for determining the sample are as follows: 1). Food and Beverages Sub-sector manufacturing industry which is listed on the Indonesia Stock Exchange for 3 consecutive years in the 2016-2018 period; 2). Manufacturing of the Food and Beverages Sub Sector which reported its financial statements for 3 consecutive years in the 2016-2018 period.

\section{Operational Definition and Variable Measurement}

Company Value $(Y)$

Mardiyanto (2009) explains that the company's value is the present value of a series of cash inflows that the company will produce in the future. One indicator used to measure company value is PER (Price Earning Ratio). According to Brigham and Houston (2006), PER is a comparison between the closing price and earnings per share. PER can be calculated by the formula:

$$
P E R=\frac{\text { Stock market price }}{\text { Earnings per share }}
$$

\section{Capital Structure (X1)}

Understanding capital structure according to Riyanto (2013) is a balance or comparison of a longterm debt with own capital. In the capital structure DER (Debt to Equity Ratio) is a ratio measuring the ability of a company to return the cost of debt through its own capital owned by the company as measured by total debt and total capital (equity).

Formulas that can be used are: 
INTERNATIONAL JOURNAL OF ACADEMIC RESEARCH IN BUSINESS AND SOCIAL SCIENCES

Vol. 10, No. 8, 2020, E-ISSN: 2222-6990 @ 2020 HRMARS

$$
\text { Debt to Equity Ratio }=\frac{\text { Total debt }}{\text { Total Equity }}
$$

\section{Liquidity (X2)}

Liquidity is a company's ability to meet its short-term obligations. Liquidity management must be able to contribute to the realization of corporate value creation (Michalski, 2010). Because, good liquidity will be considered by investors to have good performance. In this case, investors will be interested to invest their capital in the company. According to Sartono, (2000:62) liquidity can be measured by Current Ratio, which is the ratio between current assets divided by current debt.

Formulas that can be used are:

$$
\text { Current Ratio }=\frac{\text { Current asset }}{\text { Current liabilities }}
$$

Sales Growth (X3)

According to Weston and Brigham (2001) sales have a strategic influence on a company, because sales made must be supported by assets or assets and if sales are increased then assets must be added. By knowing sales from the previous year, the company can optimize existing resources. Formulas that can be used are:

$$
\text { Growth of Sales }=\frac{S 1-S t-1}{S t-1} \times 100 \%
$$

Information:

S1: sales in the t-year

St-1: sales in the previous period

\section{Data Analysis}

In this study using multiple linear regression analysis which is used to measure the effect of the dependent variable on the independent variable and predict the dependent variable using the independent variable. This analysis is also used to determine the direction of the relationship between the independent and dependent variables whether each independent variable is positively or negatively related (Priyatno, 2013:116). Before multiple linear regression analysis is performed to determine the effect of independent variables on the dependent variable together, classic assumption testing will be performed. Classical assumption testing consists of: (1) Normality Test, (2) Multicollinearity Test, (3) Heteroscedasticity Test, (4) Autocorrelation Test.

The regression equation can be formulated as follows:

$Y=\alpha+\beta 1 X 1+\beta 2 X 2+\beta 3 X 3+e$

Keterangan: $Y=$ Nilai Perusahaan

$\alpha \quad=$ Konstanta

$\beta 1 \ldots \beta n=$ Konstanta Variabel Independen

$\mathrm{X} 1=$ Variabel Struktur Modal 
INTERNATIONAL JOURNAL OF ACADEMIC RESEARCH IN BUSINESS AND SOCIAL SCIENCES Vol. 10, No. 8, 2020, E-ISSN: 2222-6990 @ 2020 HRMARS

$$
\begin{array}{ll}
\mathrm{X} 2 & =\text { Variabel Likuiditas } \\
\mathrm{X} 3 & =\text { Variabel Pertumbuhan Penjualan } \\
\mathrm{e} & =\text { Residual Eror }
\end{array}
$$

\section{Research Results and Discussion}

\section{Descriptive Statistics}

Statistical testing is done to provide an overview of data conditions. Descriptive statistics are the relationship between data collection and summarization, as well as the presentation of these results. Descriptive analysis results can be seen in the following table 1:

Table 1. Statistik Deskriptif

\begin{tabular}{|l|l|l|l|l|l|}
\hline & $\mathrm{N}$ & Minimum & Maximum & Mean & Std. Deviation \\
\hline Company value & 39 & -900.07 & 573.69 & -.1616 & 222.12074 \\
Capital structure & 39 & .09 & 2.22 & .8613 & .57652 \\
Liquidity & 39 & .56 & 7.78 & 2.2805 & 1.93974 \\
Sales growth & 39 & -.74 & 14.23 & .5236 & 2.32661 \\
Valid N (listwise) & 39 & & & & \\
\hline
\end{tabular}

Sumber: Hasil Olah Data 2020

Based on the results of table 1 the descriptive statistics above can be seen that the amount of data used in this study amounted to 39 samples, obtained from a total sample of 13 companies multiplied by the study period of 3 years (2016-2018). In the descriptive statistical table above can be seen the mean value, as well as the level of spread (standard deviation) of each variable studied. The mean value is a value that shows the magnitude of the effect of the independent variable on the dependent variable. From table 1, a description for each variable is obtained as follows: The table above shows that the company value variable measured using PER (Price Earning Ratio) has the lowest mean value of -0.1616 with a standard deviation of 222.120074 and a minimum value of -900.07 and a maximum value of 573.69. The capital structure variable in the table above also has a value of the mean is 0.8613 with a standard deviation of 0.57652 and a minimum value of 0.09 and a maximum of 2.22 .

Liquidity variable in this study has the highest mean value of 2.2805 with a standard deviation of 1.93974 and a minimum value of 0.56 and a maximum of 7.78. Sales growth variable also has a mean value of 0.5236 with a standard deviation of 2.32661 and a minimum value of -0.74 and a maximum of 14.23 .

\section{Classic assumption test Normality Test}

Normality test is carried out to find out whether the confounding or residual variables have a normal distribution or not. The normality test results can be seen through table 2 as follows: 
INTERNATIONAL JOURNAL OF ACADEMIC RESEARCH IN BUSINESS AND SOCIAL SCIENCES Vol. 10, No. 8, 2020, E-ISSN: 2222-6990 @ 2020 HRMARS

Table 2. Normality test

\begin{tabular}{|ll|l|}
\hline & & \\
\hline N & & 39 \\
& Mean & OE-7 \\
Normal Parameters ${ }^{\mathrm{a}, \mathrm{b}}$ & Std. & 198.5639806 \\
& Deviation & 6 \\
& Absolute & .185 \\
Most Extreme & Positive & .185 \\
Differences & Negative & -.176 \\
& & 1.153 \\
Kolmogorov-Smirnov Z & & .140 \\
Asymp. Sig. (2-tailed) & & \\
\hline
\end{tabular}

Sumber: Hasil Olah Data 2020

The normality test in the table above is done using the Kolmogrov-Smirnov Test one sample analysis. The results of the normality test in the study can be seen in table 2. above, where the test results show that the Asymp value. Sig (2-tailed) 0.140)> 0.05 (level of significanti). From these results it can be concluded that the regression model meets normal assumptions.Multicollinearity Test multicollinearity test was conducted with the aim to test whether the regression model found a correlation between independent variables. A good regression model should not occur between independent variables, because if that happens then the variables are not orthogonal or there is a similarity. Multicollinearity test results can be seen through table 3 as follows:

Table 3 Multicollinearty test

\begin{tabular}{|ll|l|l|}
\hline \multicolumn{2}{|l|}{ Model } & \multicolumn{2}{|l|}{ Collinearity Statistics } \\
\cline { 3 - 4 } & & Tolerance & VIF \\
\hline \multirow{2}{*}{1} & Capital structure & .550 & 1.819 \\
& Liquidity & .620 & 1.612 \\
& Sales growth & .857 & 1.166 \\
\hline
\end{tabular}

Sumber: Hasil Olah Data 2020

Based on the results of table 3 test results through the Variance Inflation Factor (VIF) on the results of the Coefficient output table, each independent variable has a VIF of no more than 10 and a Tolerance value of not less than 0.1 . So that the test results can be concluded that the independent variables tested were not multicollinearity problems occur.Heteroscedasticity TestHeteroscedasticity test is done to test whether in the regression model there is an inequality of variance from the residuals of one observation to another. A good regression model is called homoskesdatisitas or heteroscedasticity does not occur. The heteroscedasticity test can be seen in the graphic image as follows: 
INTERNATIONAL JOURNAL OF ACADEMIC RESEARCH IN BUSINESS AND SOCIAL SCIENCES Vol. 10, No. 8, 2020, E-ISSN: 2222-6990 @ 2020 HRMARS

\section{Picture 2. Heteroscedasticity test}

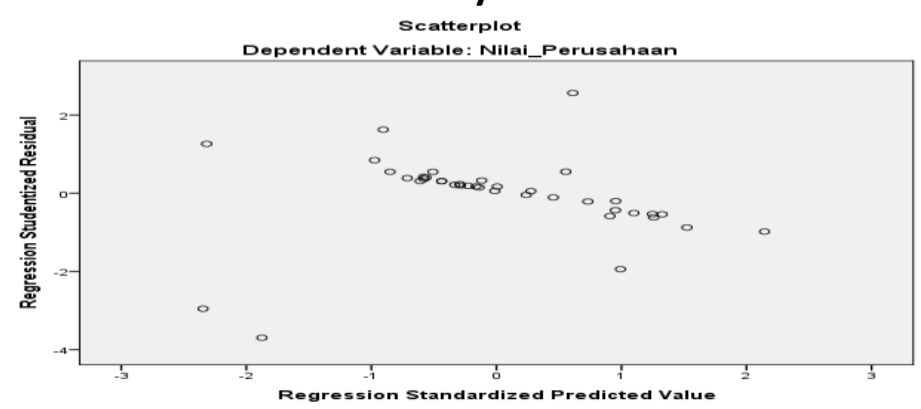

Source : Data result, 2020

The heteroscedasticity test above was carried out via scatterplot (ZPRED dependent predictive value with SRESID residuals). Based on the test results of heteroscedasticity test above, visible points spread above and below or around the number 0 . The spread of data points does not form a pattern. Then it can be concluded that the independent variable is free from the classical assumption of heteroscedasticity and is suitable for use in research.Autocorrelation TestAutocorrelation test is done with the aim to see whether there is a correlation between a period $t$ with the previous period $(t-1)$. The autocorrelation test results can be seen through table 4 as follows:

Table 4. Autocorelation test

\begin{tabular}{|l|l|l|l|l|l|}
\hline Model & $R$ & $R$ Square & $\begin{array}{l}\text { Adjusted } \\
\text { Square }\end{array}$ & $\begin{array}{l}\text { Std. Error of the } \\
\text { Estimate }\end{array}$ & Durbin-Watson \\
\hline 1 & $.448^{\mathrm{a}}$ & .201 & .132 & 206.89893 & 1.690 \\
\hline
\end{tabular}

Source : Data result, 2020

The autocorrelation test above was carried out with the Durbin Watson test (DW test). Based on the autocorrelation test results above obtained by Durbin Watson 1,690. To find out the autocorrelation area of the Durbin Watson values that is to test using the boundary table (dL) and the limit ( $\mathrm{dU}$ ) with the number of independent variables $(\mathrm{K})=3$ and the number of samples $(n)=39$, then based on the Durbin Watson table obtained $\mathrm{dL}=1.3283$ and $\mathrm{dU}=$ 1.6575 so that the results obtained are $1.6575<1,690<4-(1.6575)$ thus the decision results obtained indicate that the research data does not have autocorrelation.Multiple Linear Regression Test.

Table 5. Multiple regression test

\begin{tabular}{|ll|l|l|l|l|l|}
\hline \multicolumn{2}{|l|}{ Model } & \multicolumn{2}{|l|}{ Unstandardized Coefficients } & $\begin{array}{l}\text { Standardized } \\
\text { Coefficients }\end{array}$ & t & \multirow{2}{*}{ Sig. } \\
\cline { 3 - 6 } & B & Std. Error & Beta & & \\
\hline \multirow{2}{*}{1} & (Constant) & -302.463 & 108.985 & & -2.775 & .009 \\
& Capital structure & 225.602 & 78.514 & .586 & 2.873 & .007 \\
& Liquidity & 49.436 & 21.972 & .432 & 2.250 & .031 \\
& Sales growth & -9.063 & 15.579 & -.095 & -.582 & .564 \\
\hline
\end{tabular}

Source : Data result, 2020 
INTERNATIONAL JOURNAL OF ACADEMIC RESEARCH IN BUSINESS AND SOCIAL SCIENCES Vol. 10, No. 8, 2020, E-ISSN: 2222-6990 @ 2020 HRMARS

Based on the results of multiple linear regression testing in the table above, the regression equation is obtained as follows:

$$
Y=-302.463+225.604 X_{1}+49.436 X_{2}-0.252 X_{3}
$$

The multiple linear regression equation above can be interpreted as follows: Constants have a value of $-302,463$, this shows if the variable Capital Structure (X1), Liquidity (X2), and Sales Growth (X3) is 0 , then the variable Company Value (Y) has a value of $-302,463$. Capital Structure Variable (X1) has a regression coefficient of 225.602 which means that if the capital structure increases by one percent, then the company value will increase by $22.56 \%$. The capital structure variable regression coefficient $(X 1)$ is positive, meaning that there is a positive relationship between the capital structure variable (X1) and the firm value variable (Y). So, the increasing value of the capital structure will also be followed by an increase in the value of the company. Liquidity Variable (X2) has a regression coefficient of 49,436 which means that if liquidity increases by one percent, an increase in the value of the company will be followed by $4,943 \%$. The regression coefficient of the liquidity variable $(\mathrm{X} 2)$ is positive, meaning that there is a positive relationship between the liquidity variable $(X 2)$ and the firm value variable $(Y)$. So, increasing the value of liquidity will also be followed by increasing the value of the company. Sales Growth Variable (X3) has a regression coefficient of -9.063 , meaning that if liquidity increases by one percent, an increase in the value of the company will be followed by $-906.3 \%$. The regression coefficient of the sales growth variable (X3) is negative, meaning that there is a negative relationship between the sales growth variable $(\mathrm{X} 3)$ and the firm value variable $(\mathrm{Y})$. So, the increasing value of the capital structure is also not followed by an increase in the value of the company. The results of the multiple linear regression equation show the direction of the influence of each independent variable on the dependent variable shown by each coefficient of the independent variable. A positive independent variable regression coefficient means that the independent variable has a direct effect on Company Value. While the negative coefficient of the independent variable means that the independent variable has no influence or opposites to the Company Value.

\section{Determinant coefficient test $\left(\mathbf{R}^{2}\right)$}

Table 5. Coefficient determinant test

\begin{tabular}{|l|l|l|l|l|}
\hline Model & $R$ & R Square & Adjusted R Square & $\begin{array}{l}\text { Std. Error of the } \\
\text { Estimate }\end{array}$ \\
\hline 1 & $.448^{\mathrm{a}}$ & .201 & .132 & 206.89893 \\
\hline
\end{tabular}

Source : Data result, 2020

The coefficient of determination (Adjusted R2) seen in table 5 indicates the ability of the multiple regression equation to show the level of model explanation of the dependent variable. The magnitude of the coefficient of determination (Adjusted R2) is 0.132 or $13.2 \%$ this means that the ability of the independent variable in this case is the variable Capital Structure, Liquidity, Sales Growth and profitability simultaneously has an influence on the variable Company Value of $13.2 \%$, while the rest is $86.8 \%(100 \%-13.2 \%)$ explained by other factors outside the study. 
INTERNATIONAL JOURNAL OF ACADEMIC RESEARCH IN BUSINESS AND SOCIAL SCIENCES Vol. 10, No. 8, 2020, E-ISSN: 2222-6990 @ 2020 HRMARS

\section{Hypothesis test}

Table 6. F test

\begin{tabular}{|ll|l|l|l|l|l|}
\hline \multicolumn{2}{|l|}{ Model } & $\begin{array}{l}\text { Sum of } \\
\text { Squares }\end{array}$ & df & $\begin{array}{l}\text { Mean } \\
\text { Square }\end{array}$ & F & Sig. \\
\hline \multirow{2}{*}{1} & Regression & 376578.813 & 3 & 125526.271 & 2.932 & $.047^{\mathrm{b}}$ \\
& Residual & 1498250.868 & 35 & 42807.168 & & \\
& Total & 1874829.681 & 38 & & & \\
\hline
\end{tabular}

Source : Data result, 2020

Table 6 above shows that this equation model has a Fcount value of $(2,932)>$ Ftable of $(5 \%, 3.35)$ (2.87) and with a significance level of 0.47 . Significance value of $0.047<(0.05)$ indicates that the independent variable, namely Capital Structure, Liquidity, and Sales Growth, simultaneously has a significant effect on the Company Value. T-test or partial test is performed to determine whether the independent variable partially (individually) significantly influences the dependent variable (independent variable). A pasial test is done by comparing the t count with t table so it is often called the $t$ test. $T$ test can be seen in the table as follows:

Table 7. Hyphoteses test

\begin{tabular}{|c|c|c|c|c|c|c|}
\hline \multirow{2}{*}{\multicolumn{2}{|c|}{ Model }} & \multicolumn{2}{|c|}{$\begin{array}{c}\text { Unstandardized } \\
\text { Coefficients }\end{array}$} & \multirow{2}{*}{\begin{tabular}{|c|}
$\begin{array}{c}\text { Standardized } \\
\text { Coefficients }\end{array}$ \\
Beta \\
\end{tabular}} & \multirow[t]{2}{*}{$\mathrm{t}$} & \multirow[t]{2}{*}{ Sig. } \\
\hline & & B & Std. Error & & & \\
\hline \multirow{4}{*}{1} & (Constant) & -302.463 & 108.985 & & -2.775 & .009 \\
\hline & Capital structure & 225.602 & 78.514 & .586 & 2.873 & .007 \\
\hline & Liquidity & 49.436 & 21.972 & .432 & 2.250 & .031 \\
\hline & Sales growth & -9.063 & 15.579 & -.095 & -.582 & .564 \\
\hline
\end{tabular}

Source : Data result, 2020

\section{Discussion}

Hypothesis 1: Effect of Capital Structure on Company Value

The effect of capital structure on firm value in this study was analyzed using multiple linear regression models. Based on the results of the multiple linear regression test in table 7 above obtained a significance value of $(0.007)<0.05$ and t-value $(2887)>t$-table $(2.02)$. Then it can be concluded the first hypothesis testing states that capital structure has a positive and significant effect on firm value, so $\mathrm{H} 1$ is accepted $\mathrm{HO}$ is rejected. The results of this study are in line with the results of research from Sumarauw et al (2015) which in his research also found that capital structure has a positive and significant effect on firm value while Dhani \& Utama, (2017) research has conflicting results, that capital structure has a negative value and not significant to the company's value.

Hypothesis 2: Effect of Liquidity on Company Value

The effect of liquidity on firm value in this study was analyzed using multiple linear regression models. Based on the results of the multiple linear regression test in table 7 above, the significance value of $(0.031)<0.05$ and t-value $(2.250)>$ t-table $(2.02)$ were obtained. Then it can be concluded the second 
INTERNATIONAL JOURNAL OF ACADEMIC RESEARCH IN BUSINESS AND SOCIAL SCIENCES Vol. 10, No. 8, 2020, E-ISSN: 2222-6990 @ 2020 HRMARS

hypothesis testing states that capital structure has a positive and significant effect on firm value, so $\mathrm{H} 1$ is accepted $\mathrm{HO}$ is rejected. The results of this study are in line with the research of Astuti \& Yadnya (2019) revealed that liquidity has a positive and significant effect on firm value. However, another study was conducted by Sudiani \& Darmayanti (2016) which has conflicting results that liquidity has a negative but not significant effect on firm value.

Hypothesis 3: The Effect of Sales Growth on Company Value

The effect of liquidity on firm value in this study was analyzed using multiple linear regression models. Based on the results of the multiple linear regression test in table 7 above, the significance value of $(0.564)<0.05$ and t-value $(-0.582)<$ t-table $(2.02)$ were obtained. Then it can be concluded the third hypothesis testing states that sales growth does not have a significant effect on firm value. The results of this study are in line with research conducted by Mandalika (2016) stimulant sales growth does not have a significant relationship to the firm's value also partially does not have a significant relationship to the value of the company.

\section{Conclusion}

Based on the results of research that has been done, it can be concluded that Capital Structure variable influences Company Value. So it can be concluded that a good capital structure will have an impact on the company and indirectly the company's financial position will increase and the value of the company will be high.This research also results that the Liquidity variable also influences the Company's Value. So it can be concluded that if the liquidity value of a company is high, it will reflect the company's high ability to meet or pay short-term obligations. The results of this study prove that the Sales Growth variable does not affect Company Value. This means that the company's value cannot be reflected through an increase in sales of a company.

\section{Contributions}

This study is expected to contribute to the literature related to financial management. Management is able to make the right decisions in financial management such as capital structure, sales growth and liquidty and investors can make the right decisions in investing.

\section{Suggestion and Limitation}

Management shoud continue to pay attention and increase the value of the Capital Structure (DER) and Liquidity (CR) that affect the Company's Value. For investors, it is expected to not only see the company's Sales Growth, because the Company's Value can be reflected by looking at its Capital Structure and Liquidity. A good capital structure will have an impact on the value of the company as well as with the company's high ability to pay short-term obligations, namely liquidity. This study has several limitations, first, the observation period is limited to three years of observation. Second the variable used in direct impact in financial statement without using corporate governance variabels.

\section{References}

Astuti, N. K. B., \& Yadnya, I. P. (2019). Pengaruh Profitabilitas, Likuiditas, Dan Ukuran Perusahaan Terhadap Nilai Perusahaan Melalui Kebijakan Dividen. E-Jurnal Manajemen Universitas Udayana, 8(5), 3275. https://doi.org/10.24843/ejmunud.2019.v08.i05.p25

Brigham, Eugene, F., dan J. F. H. (2001). Book. Manajemen Keuangan. Erlangga. 
INTERNATIONAL JOURNAL OF ACADEMIC RESEARCH IN BUSINESS AND SOCIAL SCIENCES Vol. 10, No. 8, 2020, E-ISSN: 2222-6990 @ 2020 HRMARS

Brigham, E. dan H. (2006). Book. Dasar-Dasar Manajemen Keuangan (A. B. A. A. Yulianto (ed.); Edisi Sepu). Salemba Empat.

Brigham, W. J. F. dan E. F. (2001). Book. Dasar-DasarManajemen Keuangan. Erlangga.

Detiana, T. (2011). Pengaruh rasio keuangan, pertumbuhan penjualan dan dividen terdaftar harga saham. Jurnal Bisnis Dan Akuntansi, Vol. 13(2)(Sekolah Tinggi Ilmu Ekonomi Trisakti Jakarta), 119-128.

Dhani, I. P., \& Utama, A. . G. S. (2017). Pengaruh Pertumbuhan Perusahaan, Struktur Modal, Dan Profitabilitas Terhadap Nilai Perusahaan. Jurnal Riset Akuntansi Dan Bisnis Airlangga, 2(1), 135-148. https://doi.org/10.31093/jraba.v2i1.28

Husnan, S. (2001). Book. Dasar-Dasar Teori Portofolio dan Analisis Sekuritas. Unit Penerbit dan Percetakan AMP YKPN.

Kasmir. (2010). Book. Pengantar Manajemen Keuangan. Kencana.

Mandalika, A. (2016). Pengaruh Struktur Aktiva, Struktur Modal, Dan Terdaftar Di Bursa Efek Indonesia ( Studi Pada Sektor Otomotif) the Influence of Assets Structure, Capital Structure and Selling Growth To Company Value of Puclic Company Listed on Indonesia. Jurnal Berkala IImiah Efisiensi, 16(01), 207-218.

https://ejournal.unsrat.ac.id/index.php/jbie/article/download/10629/10218

Mardiyanto, H. (2009). Book. Intisari Manajemen Keuangan. Gramedia Widiasarana Indonesia.

Michalski, G. (2010). Planning Optimal From The Frim Value Creation Perspective : Levels Of Operating Cash Investments. Romanian Journal Of Economic Forecasting.

Priyatno, D. (2013). Book. Paham Analisa Statistik Data dengan SPSS. MediaKom.

RiyanRiyanto, B. (2013). Book. Dasar-Dasar Pembelanjaan Perusahaan (Keempat). BPFE.to, B. (2013). Dasar-Dasar Pembelanjaan Perusahaan (Keempat). BPFE.

Sari, O. T. (2013). Pengaruh Keputusan Investasi, Keputusan Pendanaan dan Kebijakan Dividen Terhadap Nilai Perusahaan. Management Analysis Journal, 2(2): 1-7.

Sartono, A. (2000). Book. Ringkasan teori Manajemen Keuangan Soal dan Penyelesaiannya (3rd ed.). BPFE.

Sudiani, N., \& Darmayanti, N. (2016). Pengaruh Profitabilitas, Likuiditas, Pertumbuhan, Dan Investment Opportunity Set Terhadap Nilai Perusahaan. None, 5(7), 245861.

Soebiantoro, S. dan U. (2007). Pengaruh Struktur Kepemilikan Saham, Leverage, Faktor Intern dan Faktor Ekstern terhadap Nilai Perusahaan. Jurnal Berkala Ilmiah Efisiensi, 9(01), 41-44.

Sumarauw, J., Mangantar, M., \& Rumondor, R. (2015). Pengaruh Struktur Modal, Ukuran Perusahaan Dan Risiko Perusahaan Terhadap Nilai Perusahaan Pada Sub Sektor Plastik Dan Pengemasan Di Bei. Jurnal Riset Ekonomi, Manajemen, Bisnis Dan Akuntansi, 3(3), 159-169.

Trang, I., Murni, S., \& Pantow, M. S. (2015). Analisa Pertumbuhan Penjualan, Ukuran Perusahaan, Return on Asset, Dan Struktur Modal Terhadap Nilai Perusahaan Yang Tercatat Di Indeks Lq 45. Jurnal Riset Ekonomi, Manajemen, Bisnis Dan Akuntansi, 3(1), 961-971. https://doi.org/10.35794/emba.v3i1.7801 